\title{
Ways of forgetting: Memory and identity in Alzheimer's fiction
}

\begin{abstract}
Alzheimer's is a disease that poses a challenge to the established ways of thinking about the relation between memory, identity and narrative. In this article, I offer a reading of Lisa Genova's Still Alice (2007), Stefan Merrill Block's The Story of Forgetting (2008), and Matthew Thomas's We Are Not Ourselves (2014) to examine the ways in which the increasingly popular literature of Alzheimer's represents, and possibly reconfigures, the prevalent notions of identity and memory, as well as the relation between literature and science. A number of critics have noted a shift in contemporary literature demonstrated by the growing focus on neurological conditions. Accordingly, the analysis of Alzheimer's novels refers to selected critical descriptions of this shift, including the discussions of syndrome literature and the neuronovel.
\end{abstract}

Keywords: memory, identity, Alzheimer's fiction, syndrome literature, neuronovel.

Alongside this world there's another. There are places where you can cross. Stefan Merrill Block, The Story of Forgetting (2008)

Dr. Alice Howland, the protagonist of Lisa Genova's Still Alice (2007), is "the eminent William James Professor of Psychology at Harvard University" and the author of "many of the flagship touchstones in psycholinguistics" (9). When she first notices some disturbing problems with her memory and complains to her husband, a cancer cell biologist also working in Harvard, he tries to calm her down by explaining that "Everyone's stressed. Everyone's tired. Everyone forgets things" (38). Since the problems continue, interfering with Dr. Howland's professional life, she decides to consult a neurologist and, after a series of tests, is diagnosed with early-onset Alzheimer's disease. Alice reacts to the diagnosis with terror and declares that "[s]he'd rather die than lose her mind" (78). Accordingly, she prepares for her future self a set of questions that are to test her ability to remember, and a file named "Butterfly" with suicide instructions should she fail to answer them. 
As the disease progresses, however, Alice finds it increasingly difficult not only to supply the answers, but also to remember to take the test, a process of inevitable forgetting mirrored by the shift of perspective in the novel from the woman to those around her. Spanning the period from September 2003 to September 2005, from the appearance of identifiable symptoms to the late stages of the illness, the novel traces the development of Alzheimer's and the loss of identity it entails, while insisting that, in the forgetting, Alice is still Alice.

Lisa Genova's book about "a cognitive psychology professor with a broken cognitive psyche" (198) is an example of the numerous novels dealing with Alzheimer's disease that have been published in recent years, leading to the emergence of what Stefan Block calls "the literature of Alzheimer's" (2014), a separate and burgeoning genre with its own set of themes and conventions. ${ }^{12}$ In this article, I refer to Genova's Still Alice (2007), Stefan Merrill Block's The Story of Forgetting (2008), and Matthew Thomas's We Are Not Ourselves (2014) as examples of Alzheimer's literature in order to examine the ways in which such fiction represents, and possibly reconfigures, the prevalent notions of memory and identity, as well as the relation between literature and science. The focus on neurological conditions in Alzheimer's fiction reflects a larger transformation in contemporary literature, a shift which Patricia Waugh has aptly called "the naturalistic turn" (2013) and which other critics have described as the rise of syndrome fiction (Lustig and Peacock, 2013) or of the neuronovel (Roth, 2009). While this turn to neurological disorders to re-consider the meaning of the human and the biological lies at the centre of Alzheimer's novels, it is also present in other kinds of fiction, such as Lance Olsen's Theories of Forgetting (2014). Olsen's postmodern book, similarly to the Alzheimer's novels discussed in this article, dwells on acts of forgetting and remembering to foreground the process of dissolution of the various boundaries - between the brain and the mind, the self and others, or art and science - that may point to some new ways of thinking about memory, identity and narrative.

What distinguishes Alzheimer's fiction from other contemporary genres is its semi-documentary character and the intention, sometimes explicitly expressed, to shape the public perception of the illness and those suffering from it. Frequently, the books are based on the writers' personal experience: Genova, whose grandmother suffered from dementia, holds a Ph.D. in neuroscience and contributes articles to the National Alzheimer's Association website; Matthew Thomas's We Are Not Ourselves (2014) was inspired by his father's early-onset Alzheimer's; the memory of Stefan Merrill Block's grandmother lies behind The Story of Forgetting (2008); Jean Lee's Alzheimer's Daughter (2015) recounts the story of her parents' struggle with the disease; and Shannon Wiersbitzky points to the experience with her grandfather as the inspiration for What Flowers Remember (2014). In many of the novels, the detailed descriptions of the disease and its treatment serve as guides for those affected by the illness and their families: the narrator of Block's The Story of Forgetting, for example, recounts the latest findings and outlines the possible future directions in

12 The success of the 2014 movie based on Genova's novel testifies to the growing popularity of Alzheimer's fiction as well as to the concomitant need to translate and represent the experience of the disease in various narrative forms. 
Alzheimer's research, and the protagonist of Genova's novel joins the Alzheimer's Association and participates in the annual Dementia Care Conference. In addition to including information about the existing organizations and treatment, some of the novels provide lists of the institutions dedicated to Alzheimer's patients and caregivers, and advocate for financial support for Alzheimer's research. By adopting such strategies, Alzheimer's fiction attempts to move beyond the level of imaginative description to intervene in the real problems encountered by the readers and to combat the social stigma frequently attached to those suffering from the disease.

The problems of the lack of communal support and the status of Alzheimer's patients as social outcasts recur in numerous novels, whose protagonists experience various degrees of exile and alienation. Thus, in We Are Not Ourselves, Eileen Leary, taking care of her demented husband Edmund, is abandoned by her friends, so that "[t]hey were staying home on New Year's Eve for the first time in the twenty-eight years since they'd met" (Thomas, 384), as well as by her son, who escapes from his father's illness to a far away college, hoping that "the farther he went, the harder it would be to come back" (Thomas, 397). In Still Alice, Dr. Howland envies the people suffering from cancer since they "could expect to be supported by their community. Alice expected to be cast out" (Genova, 118), and in The Story of Forgetting, the ailing Jamie, whose favourite novel is Jane Eyre (Block, 84), immediately after the diagnosis is placed by her husband in Willow Acres Assisted Care Facility, renamed by her son as "The Waiting Room" (Block, 83). Alzheimer's, as the narrator of The Story of Forgetting states, has risen "in the public consciousness to the rank of true epidemic" (Block, 303), a "mysterious" and strangely ubiquitous illness feared by nearly everyone. The fact that, as Susan Sontag claims in Illness as Metaphor, "any disease that is treated as a mystery and acutely enough feared will be felt to be morally, if not literally, contagious" (6) may provide one explanation for the interventionist character of the literature of Alzheimer's, in particular for its attempts to bridge the long-established gap between science and fiction.

The fear that underlies the public response to Alzheimer's and that forms the core of the novels is that of the loss of memory and the ensuing loss of identity. Alzheimer's is commonly perceived as synonymous with forgetting, in particular with short-term memory loss, although its symptoms include various other impairments, such as deteriorating emotional control, social behaviour or motivation (Robert, 129). If, as Susannah Radstone writes, "memories make us" (19), and if "memory is above all a form of representation" (Passerini, 238), then the loss of memory makes it impossible to construct narratives, including the story of one's self. In Alzheimer's fiction, the loss of memory is almost invariably translated into the loss of self, even if, as the narrator of The Story of Forgetting admits, "it's not just memories that people with [the] disease forget but increasingly basic things. How to write, how to speak, how to walk, how to sit up, how to swallow, how to breathe, and ... how to stay alive" (Block, 51).

The connection between identity and memory is positioned at the centre of Alzheimer's novels, leading to the questioning of what constitutes a self both for the individual and for others, but also signalling a shift of perspective in approaching the relation between identity, memory and narrative. The progressive neurodegenerative disease makes forgetting inevitable, gradually depriving 
the sufferers of the basic and seemingly stable coordinates of identity and forcing them to radically change their lives. In Still Alice, the prospect of having to give up her job leads the protagonist to question her own identity, not knowing "Who was she if she wasn't a Harvard psychology professor?" (Genova, 96), while the gradual loss of speech makes her interrogate the very distinctiveness of humans: "Her ability to use language, that thing that most separates humans from animals, was leaving her, and she was feeling less and less human as it departed" (Genova, 270). A similar set of questions appears in We Are Not Ourselves, where Edmund, a professor at Bronx Community College and "an expert on the brain" (Thomas, 73) suffering from early-onset Alzheimer's, confesses to feeling like "one of [his] rats" (Thomas, 333), the animals he used in his lab to test "the effects of psychotropic drugs on neural functioning" (Thomas, 73). For Alice, the feature defining humans is the ability to use language, and for Ed it is the possibility to learn - as he states, "If we don't learn, we die" (Thomas, 180); both are seen as essential components of identity in contemporary critical and literary texts, and both are lost in Alzheimer's disease. Rather than pointing to the original emptiness of the self or to the bankruptcy of the concept, however, the stories of memory loss may suggest the need to rethink the prevailing notions of selfhood in order to take into account the fact that, as Ed's wife states, “[h]is real self wasn't hiding in there waiting to be sprung for a day of freedom. This was his real self now" (Thomas, 334).

Commenting on the recent developments in literature, a number of critics have pointed to the increasing use of neurological conditions as indicative of a major shift in fiction and in the conceptualization of selfhood. Thus, Patricia Waugh describes "the naturalistic turn" away from the "hermeneutic sense of selfhood as a complex and dynamic reframing of experience" and the concomitant "medicalization of the mind" as the key characteristics of the literature succeeding postmodernism (2013: 20). T. J. Lustig and James Peacock, in turn, portray the shift as the rise of syndrome fiction, which focuses on the exploration of the "neurological, and also genetic factors, affecting human existence" and in which "the self, bound up in any number of complex systems, is largely determined not by its choices or its past, but by the very cells with which it becomes aware (or ceases to be) or by its own conditioning" (10). According to Lustig and Peacock, a key feature of syndrome novels is a "reinvigorated embrace of science" that alters "our sense of how the world works" (9), and that may suggest a return to the biological and the human. In "The Rise of the Neuronovel," Marco Roth offers perhaps the most radical - and controversial - description of the new fiction, claiming that it reflects a larger cultural movement "away from environmental and relational theories of personality back to the study of brains themselves, as the source of who we are" (2009). In the neuronovel, as Roth argues, the mind becomes the brain and the self is lost, to literature at least, as it is turned into "an object whose intricacies can only be described by future science" or by specialists "writing in the idioms of their disciplines" (2009). The neuronovel demonstrates the decline of the novel, if not its death, as a form which, as Roth claims, can merely register the failure of "the metaphoric impulse" and present its readers with "the experience of a cognitive defeat" (2009). 
As Alzheimer's novels, Still Alice, The Story of Forgetting, and We Are Not Ourselves are records of cognitive defeat, though perhaps not as absolute as Roth would have it and not for the reader. While the novels medicalize the mind and explore the neurological and genetic determinants dissolving the self, frequently adopting a specialized language, they do so in a way that produces rather than defies metaphorization. The metaphor that consistently returns in these books is the belief that, as memories are taken away as the disease progresses, the core components of selfhood are revealed, showing the "real self" that exceeds the record of past experiences and choices. Sontag dates the emergence of this "romantic idea that the disease expresses the character" back to the nineteenth century (46). This portrayal of disease as "a form of self-expression" (Sontag, 44) returns in Alzheimer's fiction to argue for the persistence of emotions when cognitive functions fail. The protagonist of Still Alice continues to be defined by her love for the family members she no longer recognizes; in We Are Not Ourselves, Ed is distinguished by "a naked desire to please" his wife (429); and Jamie in The Story of Forgetting is driven by the visceral longing to return to her family home from which she escaped when she turned eighteen in an attempt to forget about her past. Inasmuch as emotions are presented as delineating a stable core of the self, however, they are revealed only through and in relations to others, thereby portraying this self as relational and unstable, "formed through interaction with others" (Basting, 80). As the novels suggest, it is the task of the significant others to remember and re-constitute the self, as well as to preserve memories. In Still Alice, Alice's Ph.D. student begins every conversation with telling her who she is, and her children prepare for her a video memoir titled "The Howlands Kids" with their memories of her; in We Are Not Ourselves, Connell realizes that the memories about his father are preserved in the latter's "contribution to science; ... the altered lives of the students he'd taught, and the impacts those students had had, and would have, on others" (Thomas, 588). Ultimately, as Connell states, the memories will stay in himself, "his father's real estate" (Thomas, 588), preserved through the genetic code that may contain the genes of Alzheimer's disease.

While memory and genetics are an important theme of Genova's Still Alice and Thomas's We Are Not Ourselves, they are the explicit focus of Block's The Story of Forgetting, which includes extensive descriptions of the research on memory, real and imagined, in the parts titled "Genetic History." Seth, one of the novel's narrators, decides "to become an expert on the human brain" (24) when his mother is diagnosed with early-onset Alzheimer's, and he sets out to construct her genetic history as his "first official research project" (95). This leads him to investigate the findings on familial early-onset Alzheimer's by Dr. Marvin Shellard, a fictitious scientist who discovers the roots of the disease in Lord Alban Mapplethorpe, "a scion of the Mapplethorpe family of Iddylwahl, England (now long since wiped from map and memory alike)" (53), whose offspring carried the illness centuries ago to all parts of the world. Seth's search is based on the finding that "any one sufferer of EOA23 Morbus Alzheimer is at most the twelfth or thirteenth cousin of any other" (51). Accordingly, it is the search for his own family past in order to fill the gaps in his memory which, unlike the gaps in his mother's, are not "the result of a disease" and thus "beyond ... control," but are "deliberate," the effect of his parents' decision 
to forget their past when they left their homes and started their life together (198). The gaps in Seth's memory are filled for the reader by the stories of Abel, the other narrator in the novel and the boy's grandfather, who recounts the long history of his family's curse of forgetting. For Seth, they are completed at the end of the novel when, following the map of Isidora, a place from his mother's childhood stories which she claims is real (27), he takes Jamie from the Waiting Room to her long-lost home and father.

Like Alzheimer's genes, the story of Isidora has been passed in Seth's family from generation to generation "for potentially hundreds of years" (27), forming another kind of heritage and a proof of common descent. This "land without memory" (174) is inhabited by people who "can't hold on to any memory, even the memory of death" (38), and who use a language that "is based not on words but on touch" (62), conducting "one another's feelings through their hands" (75). In this place "where every need is met and every sadness is forgotten" (13), the only kind of memory that is known is that of every Isidoran's death which is remembered by the earth, so that "each step across the cemetery" fills the Isidorans "with the startling sensations of their ancestors' final moments, the corpses conducting their own epitaphs" (75). The kingdom of Isidora exists alongside the real world as its uncanny double, and there are secret passages that can take one there. Such a passage is found by a little girl from Earth who brings with her "words and thoughts and memories," showing Isidorans how "to remember, to think, and to speak" (201). The new skills lead them to try to understand death and, because of the different opinions on the nature of the Total Memory which they claim follows the end of life, the War of Isidora breaks out. Some Isidorans see the Total Memory as a "reunion with all they ha[ve] lost," others hold it tantamount to shedding "one's self into something far greater," and still others argue that "the afterlife [is] identical to life, with the exception that all other Isidorans' motives and desires and needs [are] known and so there [can] never be misunderstandings" (201). In the midst of the war, there appears another group of Isidorans who dream, "instead of Total Memory, of no memory at all" and of "a return to the blissful amnesia of Isidora's past" (201). Desiring "to discover a way to forget" (237), they form the Amnesia Club and restore Isidora in microcosm by placing their children in a secret cave, with no memory of their land. This Isidora "in miniature" that is "buried deep underground" (238) is visited once in a generation by an outsider in order to choose a boy or a girl to carry "the Great Burden" and "to be the only descendant of the Amnesia Club to remain with the memory of it all, to take sole responsibility for seeing that those hidden underground [are] protected and left alone" (237).

The "idea of Isidora," as The Story of Forgetting claims, "has always been as important as Isidora itself," since without it, we would be left "blind to fumble and crash about our things" (292). This reversed image of the real world provides both the imaginative space to tell the stories of those who can no longer remember and a different idiom to recount the discoveries of science. The stories of Jamie, her son's search for her genetic history, and her father's family curse are situated alongside those of neurological malfunctions, including that of "a German woman, named Auguste D., who came into the office of Dr. Alois Alzheimer and explained to the doctor, 'I have lost myself'” (50). 
The novel gives Alzheimer's a (family) history, positioning it between the cases of the famous amnesiac Henry Molaison, who lost the ability to make new memories after a brain surgery in 1953, but kept "all of his memories before the surgery perfectly intact, his mind frozen in an endless present" (80), and of Solomon Shereshevsky, who could "remember everything," but could not "find patterns in anything" (80) and to whom theorists refer "to support the hypothesis that our success as a species is based as much, if not more, on our ability to forget than on our ability to remember" (81). It also gives Alzheimer's a context, setting it against such disorders as Cotard's syndrome, the Fregoli delusion, "forms of coma in which sufferers are conscious and receptive yet totally unable to respond externally," and adrenoleukodystrophy (81). From the perspective of the various malfunctions listed in the novel, the concept of memory itself becomes hard to define, and the difficulty is reinforced by the fact that "new forms of memory [are] invented all the time: instinctual memory, procedural memory, sensory memory, short-term memory" (240), or, most importantly perhaps, transactive memory (212), where the task of encoding, preserving and recalling memories becomes a shared, and not individual responsibility.

Describing the "aesthetic sensation a reader gets from the neuronovel," Roth states that it "is not the pleasure of finding the general in the particular, but a frustration born of the defeat of the metaphoric impulse" (2009). The multiplicity of stories that span centuries and that are woven around an individual suffering from Alzheimer's in The Story of Forgetting, or the fact that the story of Eileen's husband in We Are Not Ourselves is a part of the history of her family that covers several decades, seem to question this description. Additionally, Alzheimer's fiction can be seen as an example of the social novel, using the description of individual problems to form communities both within and without the books, thereby finding the general in the particular. This movement is repeated in the novels' presentation of the relation between memory and identity, where the responsibility to preserve the forgetting self and its memories is relocated onto others. The communities in and outside the novels are frequently constructed around scientists and science, thus emphasising its growing importance, but also moving towards dissolving the boundaries between science and literature which, no longer incompatible, are both called for to describe and explain the process of dissolution. Even though, as Eileen states after her husband's death in We Are Not Ourselves, Alzheimer's may be the point where "science ha[s] reached the end of its utility" (Thomas, 569), it continues to be represented in Alzheimer's novels as a viable and important option. Significantly, Still Alice, We Are Not Ourselves, and The Story of Forgetting end with deaths but not with a rejection of science: Alice's husband continues his cancer research; Connell, Ed's son, becomes a teacher, like his father; and Seth ends his narrative as "a third-year graduate student in Marvin Shellard's Neurodegenerative Studies Lab," spending his days "taking measurements of what can be measured, gathering oral histories, entering data, correlating the findings" (Block, 309). This embracement of science, however, is not entirely optimistic, but is marked by a guarded hopefulness checked by the awareness of the limits of what can be measured, and the possibility of failure, driven by "a kind of informed naivety, a pragmatic idealism" 
(Vermeulen and Akker, 5) that form the structure of feeling that dominates in the period following the postmodern.

The dominant sense of loss and weariness suffused with hope may be the best description of Alzheimer's fiction, inscribing it within the general mood that permeates contemporary cultural production. Lustig and Peacock write that the focus on neurological conditions in syndrome novels and their embracement of science may reflect a wider "paradigm shift in our understanding of the world and of ourselves" (5) towards "a new post-humanism, where certain kinds of value relocate from their old centre in 'man' and take up residence in complex systems like the bloodstream or the cosmos or the living environment" (11). This movement away from the "man" as centre is registered by the literature of Alzheimer's, which dissociates the locus of the self from the individual and moves it into more complex systems - generations, genetics, neuroscience, evolution, or, as in the case of the Isidoran earth which remembers, the living environment - to reconfigure dissolution as re-composition. This movement is also the guiding principle of Lance Olsen's Theories of Forgetting (2014), an experimental novel which presents the mechanisms of remembering and forgetting as an ongoing and inevitable process of de- and re-composition that is simultaneously entropic and productive. Olsen's book is composed of three parts: the story of Alana, who, while working on a documentary about Robert Smithson's Spiral Jetty, falls victim to the pandemic called The Frost, which causes gradual amnesia; the record of the slow disappearance of Alana's husband, Hugh, on a journey he makes after her death; and the comments of their daughter, Aila, which are transcribed across her father's manuscript and which are addressed to her brother, Lance. The accounts by Alana, Hugh and Aila are interspersed with photographs, some still and some in motion, and with quotes from famous critics and artists, including Roland Barthes, Jean Baudrillard and John Cage. Each page of the book is divided in half, with one of the stories printed upside down, and with one text running from front to back and the other from back to front. The linearity of the narrative is further interrupted by the fact that the book has no front cover, but instead features the same back page at its beginning and end. Accordingly, the choice of what constitutes the novel, how it is read and remembered, depends on the reader. Theories of Forgetting should be described as formed by a series of surfaces rather than by pages which, like memories, can be infinitely re-arranged and reconfigured. Subtitled A Novel After Robert Smithton, the book returns to the artist's most famous earthwork Spiral Jetty (1970) at Great Salt Lake, Utah, and to his concept of entropy in order to emphasize the ubiquity of progressive dissolution, also of the boundaries between science and art. Referring to physics, Smithton defined entropy as "in the first instance a measure of something that happens when one state is transformed into another" (21). Theories of Forgetting returns to this concept to re-present dedifferentiation and to theorize decay "not merely as a process of emptying and exhaustion, but also as one of relay \& salvage" (Olsen, 99). The awareness of the inevitability of such transformation, as well as the constant relaying and salvaging of memories and identities, lie at the core of Alzheimer's fiction, which, like Seth's living environment in The Story of Forgetting, may turn into "a case study on the principles of entropy" (Block, 76), on the various ways of forgetting, and the possibilities of (literary) remembering. 


\section{References:}

Basting, Anne Davis. 2001. “God Is a Talking Horse': Dementia and the Performance of Self." TDR 45.3, 78-94.

Block, Stefan Merrill. 2008. The Story of Forgetting: A Novel. New York: Random House.

Block, Stefan Merrill. 2014. "A Place Beyond Words: The Literature of Alzheimer's." The New Yorker 20 Aug. 2014. 8 Oct. 2016. www.newyorker.com/books/page-turner/place-beyond-wordsliterature-alzheimers

Genova, Lisa. 2009 [2007]. Still Alice. New York: Pocket Books.

Lustig, T. J. and James Peacock. 2013. "Introduction." Diseases and Disorders in Contemporary Fiction: The Syndrome Syndrome. Ed. T. J. Lustig and James Peacock. New York and London: Routledge, 1-16.

Olsen, Lance. 2014. Theories of Forgetting. Tuscaloosa: The University of Alabama Press.

Passerini, Luisa. 2003. "Memories Between Silence and Oblivion." Contested Pasts: The Politics of Memory. Ed. Katharine Hodgkin and Susannah Radstone. New York: Routledge, 238-254.

Radstone, Susannah. 2000. "Working with Memory: An Introduction." Memory and Methodology. Ed. Susannah Radstone. New York: Berg, 1-20.

Robert, Philippe H. 2003. "Psychiatric and Behavioral Problems: Pharmacological Approaches." The Clinical Management of Early Alzheimer's Disease: A Handbook. Ed. Reinhild Mulligan, Martial Van Der Linden, and Anne-Claude Juillerat. Mahwah: Lawrence Erlbaum Associates, 129-142.

Roth, Marco. 2009. “The Rise of the Neuronovel.” N+ 8, 139-148. 20 Sept. 2016. nplusonemag.com/ issue-8/essays/the-rise-of-the-neuronovel/

Smithton, Robert. 1996. "Entropy and the New Monuments." Robert Smithson: The Collected Writings. Ed. Jack Flam. Berkeley: University of California Press, 10-23.

Sontag, Susan. 1978. Illness as Metaphor. New York: Farrar, Strauss and Giroux.

Thomas, Matthew. 2014. We Are Not Ourselves: A Novel. London, New York: Simon \& Shuster.

Vermeulen, Timotheus and Robin van den Akker. 2010. "Notes on Metamodernism." Journal of Aesthetics and Culture 2, 1-13. 22 May 2012. dx.doi.org/10.3402/jac.v2i0.5677

Waugh, Patricia. 2013. "The Naturalistic Turn, the Syndrome, and the Rise of the NeoPhenomenological Novel." Diseases and Disorders in Contemporary Fiction: The Syndrome Syndrome. Ed. T. J. Lustig and James Peacock. New York and London: Routledge, 17-34. 